\title{
The $\mathrm{GABA}_{\mathrm{B} 1 \mathrm{a}}$ Isoform Mediates Heterosynaptic Depression at Hippocampal Mossy Fiber Synapses
}

\author{
Nicole Guetg, ${ }^{1,3 *}$ Riad Seddik, ${ }^{1 *}$ Réjan Vigot, ${ }^{1}$ Rostislav Turecek, ${ }^{1}$ Martin Gassmann, ${ }^{1}$ Kaspar E. Vogt, ${ }^{2}$ \\ Hans Bräuner-Osborne, ${ }^{1,4}$ Ryuichi Shigemoto, ${ }^{5,6,7}$ Oliver Kretz, ${ }^{3}$ Michael Frotscher, ${ }^{3}$ Ákos Kulik, ${ }^{3}$ and Bernhard Bettler ${ }^{1}$ \\ ${ }^{1}$ Department of Biomedicine, Institute of Physiology, Pharmazentrum, and ${ }^{2}$ Division of Pharmacology and Neurobiology, Biozentrum, University of Basel, \\ 4056 Basel, Switzerland, ${ }^{3}$ Institute of Anatomy and Cell Biology, Department of Neuroanatomy, University of Freiburg, 79104 Freiburg, Germany, \\ ${ }^{4}$ Department of Medicinal Chemistry, Faculty of Pharmaceutical Sciences, University of Copenhagen, 2100 Copenhagen, Denmark, ${ }^{5}$ Division of Cerebral \\ Structure, National Institute for Physiological Sciences, and ${ }^{6}$ Department of Physiological Sciences, The Graduate University of Advanced Studies \\ (Sokendai), Myodaiji, Okazaki 444-8787, Japan, and ${ }^{7}$ Solution Oriented Research for Science and Technology, Japan Science and Technology Corporation, \\ Kawaguchi 332-0012, Japan
}

$\mathrm{GABA}_{\mathrm{B}}$ receptor subtypes are based on the subunit isoforms $\mathrm{GABA}_{\mathrm{B} 1 \mathrm{a}}$ and $\mathrm{GABA}_{\mathrm{B} 1 \mathrm{~b}}$, which associate with $\mathrm{GABA}_{\mathrm{B} 2}$ subunits to form pharmacologically indistinguishable $\mathrm{GABA}_{\mathrm{B}(1 \mathrm{a}, 2)}$ and $\mathrm{GABA}_{\mathrm{B}(1 \mathrm{~b}, 2)}$ receptors. Studies with mice selectively expressing $\mathrm{GABA}_{\mathrm{B} 1 \mathrm{a}}$ or $\mathrm{GABA}_{\mathrm{B} 1 \mathrm{~b}}$ subunits revealed that $\mathrm{GABA}_{\mathrm{B}(1 \mathrm{a}, 2)}$ receptors are more abundant than $\mathrm{GABA}_{\mathrm{B}(1 \mathrm{~b}, 2)}$ receptors at glutamatergic terminals. Accordingly, it was found that $\mathrm{GABA}_{\mathrm{B}(1 \mathrm{a}, 2)}$ receptors are more efficient than $\mathrm{GABA}_{\mathrm{B}(1 \mathrm{~b}, 2)}$ receptors in inhibiting glutamate release when maximally activated by exogenous application of the agonist baclofen. Here, we used a combination of genetic, ultrastructural and electrophysiological approaches to analyze to what extent $\mathrm{GABA}_{\mathrm{B}(1 \mathrm{a}, 2)}$ and $\mathrm{GABA}_{\mathrm{B}(1 \mathrm{~b}, 2)}$ receptors inhibit glutamate release in response to physiological activation. We first show that at hippocampal mossy fiber (MF)-CA3 pyramidal neuron synapses more $\mathrm{GABA}_{\mathrm{B} 1 \mathrm{a}}$ than $\mathrm{GABA}_{\mathrm{B} 1 \mathrm{~b}}$ protein is present at presynaptic sites, consistent with the findings at other glutamatergic synapses. In the presence of baclofen at concentrations $\geq 1 \mu \mathrm{m}$, both $\mathrm{GABA}_{\mathrm{B}(1 \mathrm{a}, 2)}$ and $\mathrm{GABA}_{\mathrm{B}(1 \mathrm{~b}, 2)}$ receptors contribute to presynaptic inhibition of glutamate release. However, at lower concentrations of baclofen, selectively $\mathrm{GABA}_{\mathrm{B}(1 \mathrm{a}, 2)}$ receptors contribute to presynaptic inhibition. Remarkably, exclusively $\mathrm{GABA}_{\mathrm{B}(1 \mathrm{a}, 2)}$ receptors inhibit glutamate release in response to synaptically released GABA. Specifically, we demonstrate that selectively $\mathrm{GABA}_{\mathrm{B}(1 \mathrm{a}, 2)}$ receptors mediate heterosynaptic depression of MF transmission, a physiological phenomenon involving transsynaptic inhibition of glutamate release via presynaptic $\mathrm{GABA}_{\mathrm{B}}$ receptors. Our data demonstrate that the difference in $\mathrm{GABA}_{\mathrm{B} 1 \mathrm{a}}$ and $\mathrm{GABA}_{\mathrm{B} 1 \mathrm{~b}}$ protein levels at MF terminals is sufficient to produce a strictly $\mathrm{GABA}_{\mathrm{B} 1 \mathrm{a}}$-specific effect under physiological conditions. This consolidates that the differential subcellular localization of the $\mathrm{GABA}_{\mathrm{B} 1 \mathrm{a}}$ and $\mathrm{GABA}_{\mathrm{B} 1 \mathrm{~b}}$ proteins is of regulatory relevance.

Key words: GABA(B); GABA-B; metabotropic; hippocampus; presynaptic inhibition; heteroreceptor

\section{Introduction}

$\mathrm{GABA}_{\mathrm{B}}$ receptors are the G-protein coupled receptors for $\gamma$-aminobutyric acid (GABA), the main inhibitory neurotransmitter in the CNS. They have been implicated in a variety of disorders, including cognitive impairments, anxiety, depression and epilepsy (Calver et al., 2002; Bettler et al., 2004). Presynaptic $\mathrm{GABA}_{\mathrm{B}}$ receptors inhibit neurotransmitter release via the inhibition of $\mathrm{Ca}^{2+}$ channels and second-messenger-mediated effects

Received Aug. 5, 2008; revised Dec. 2, 2008; accepted Dec. 31, 2008.

This work was supported by Neurex (B.B., M.F.), the Swiss Science Foundation (3100A0-117816; B.B.), and the Deutsche Forschungsgemeinschaft Sonderforschungsbereich 505/780 (A.K., M.F.). We thank A. Schneider, S. Nestel, and B. Joch for technical assistance, V. Besseyrias for breeding and genotyping of mice, and J. Tiao and D. Ulrich for comments on this manuscript.

The authors declare no competing financial interests.

*N.G. and R.S. contributed equally to this work.

Correspondence should be addressed to either of the following: Bernhard Bettler, Department of Biomedicine, Institute of Physiology, Pharmazentrum, University of Basel, CH-4056 Basel, Switzerland, E-mail: bernhard.bettler@unibas.ch; or Ákos Kulik, Institute of Anatomy and Cell Biology, Department of Neuroanatomy, University of Freiburg, Albertstrasse 17, D-79104 Freiburg, Germany, E-mail: akos.kulik@anat.uni-freiburg.de.

DOI:10.1523/JNEUROSCI.3697-08.2009

Copyright $\odot 2009$ Society for Neuroscience $\quad$ 0270-6474/09/291414-10\$15.00/0 downstream of $\mathrm{Ca}^{2+}$ entry (Scanziani et al., 1992; Jarolimek and Misgeld, 1997; Yamada et al., 1999; Sakaba and Neher, 2003). They are commonly divided into autoreceptors and heteroreceptors depending on whether they control the release of GABA or other neurotransmitters, respectively. Postsynaptic $\mathrm{GABA}_{\mathrm{B}}$ receptors activate Kir3-type $\mathrm{K}^{+}$channels, which induces slow inhibitory potentials and mediates shunting inhibition (Lüscher et al., 1997). The physiological functions of $\mathrm{GABA}_{\mathrm{B}}$ receptors have been mostly inferred from electrophysiological experiments in which the receptors were pharmacologically activated by exogenous application of the agonist baclofen. Physiological activation of $\mathrm{GABA}_{\mathrm{B}}$ receptors usually requires strong stimulus intensities, suggesting that pooling of synaptically released GABA is required to activate them (Isaacson et al., 1993; Scanziani, 2000). This agrees with ultrastructural data demonstrating that most $\mathrm{GABA}_{\mathrm{B}}$ receptors are located distant from release sites (López-Bendito et al., 2004; Lacey et al., 2005; Kulik et al., 2006). A tonic activation of $\mathrm{GABA}_{\mathrm{B}}$ receptors through ambient GABA was also observed, which may partly explain their predominantly extrasynaptic lo- 
calization as well (Lei and McBain, 2003; Price et al., 2005; Liu et al., 2006).

$\mathrm{GABA}_{\mathrm{B}}$ receptors are heteromers composed of $\mathrm{GABA}_{\mathrm{B} 1}$ and $\mathrm{GABA}_{\mathrm{B} 2}$ subunits (Calver et al., 2002; Bettler et al., 2004). The only molecular distinction in the $\mathrm{GABA}_{\mathrm{B}}$ receptor system is based on the subunit isoforms $\mathrm{GABA}_{\mathrm{Bla}}$ and $\mathrm{GABA}_{\mathrm{B} 1 \mathrm{~b}}$, which differ in their ectodomains by a pair of "sushi domains" that are unique to $\mathrm{GABA}_{\mathrm{Bla}}$ (Hawrot et al., 1998). Heteromeric $\mathrm{GABA}_{\mathrm{B}(1 \mathrm{a}, 2)}$ and $\mathrm{GABA}_{\mathrm{B}(1 \mathrm{1b}, 2)}$ receptors do not exhibit pharmacological differences and couple to the same effector systems in transfected cells. To address the reason for the existence of two receptor subtypes we generated $\mathrm{GABA}_{\mathrm{Bla}}{ }^{-l-}\left(1 \mathrm{a}^{-/-}\right)$and $\mathrm{GABA}_{\mathrm{Blb}}{ }^{-1-}\left(1 \mathrm{~b}^{-l-}\right)$ mice, which express either one or the other $\mathrm{GABA}_{\mathrm{B} 1}$ subunit isoform. Pharmacological studies with these mice suggest that $G_{A B A_{B 1 a}}$ and $G_{A B A}$ B1b differentially influence synaptic functions, primarily as a result of their distinct distributions to axonal and dendritic compartments (Ulrich and Bettler, 2007). In principle, since $\mathrm{GABA}_{\mathrm{B} 1 \mathrm{a}}$ and $\mathrm{GABA}_{\mathrm{B} 1 \mathrm{~b}}$ subunits are independently regulated at the transcriptional level (Steiger et al., 2004), this allows for dynamically adjustable $\mathrm{GABA}_{\mathrm{B}}$ signaling at axonal and dendritic effectors. However, to clearly establish a regulatory significance for $\mathrm{GABA}_{\mathrm{B}}$ receptor subtypes, it needs to be demonstrated that they not only yield differential effects in response to pharmacological activation, but also in response to physiological activation (Huang, 2006). A physiological phenomenon proposed to rely on the endogenous activation of $\mathrm{GABA}_{\mathrm{B}}$ heteroreceptors is heterosynaptic depression (Isaacson et al., 1993; Vogt and Nicoll, 1999; Chandler et al., 2003). Here, we studied heterosynaptic depression at MF-CA3 pyramidal neuron synapses to address to what extent the two $\mathrm{GABA}_{\mathrm{B}}$ receptor subtypes inhibit glutamate release in response to activation by synaptically released GABA.

\section{Materials and Methods}

Mutant mouse strains. The generation of $1 \mathrm{a}^{-1-}$ and $1 \mathrm{~b}^{-1-}$ mice was described previously (Vigot et al., 2006). For control experiments we additionally used $\mathrm{GABA}_{\mathrm{B} 1}$-deficient $\left(1^{-/-}\right)$mice that completely lack $\mathrm{GABA}_{\mathrm{B} 1}$ protein (Schuler et al., 2001). Homozygous mutant mice and wild-type (WT) littermate mice were obtained by breeding heterozygous mice on a pure inbred BALB/c genetic background. All animal experiments were subjected to institutional review and approved by the veterinary office of Basel-Stadt.

Pre-embedding immunocytochemistry and quantitative analysis. Preembedding $\mathrm{GABA}_{\mathrm{B} 1}$ immunogold labeling and electron microscopy was done as described, using affinity-purified guinea pig polyclonal antiserum $\mathrm{B} 62$ raised against the C-terminal 103 amino acid residues of $\mathrm{GABA}_{\mathrm{B} \text { la }_{\mathrm{a}}}$ and $\mathrm{GABA}_{\mathrm{B} 1 \mathrm{~b}}$ (Kulik et al., 2006). Light microscopy confirmed that the $\mathrm{B} 62$ antiserum immunostains WT, $1 \mathrm{a}^{-1-}$, and $1 \mathrm{~b}^{-1-}$ hippocampal sections, but not $1^{-1-}$ sections (data not shown). Preembedding electron microscopy showed a reduction of the immunogold particle density by $86 \%$ in $1^{-/-}$hippocampal sections compared with WT sections, which agrees well with earlier control experiments where the reduction of immunogold particles in $1^{-/-}$sections was $88 \%$ (Vigot et al., 2006). Immunogold particles that nonspecifically labeled $1^{-/-}$ sections were approximately equally distributed over presynaptic and postsynaptic membranes, as described (Vigot et al., 2006). Preembedding electron microscopy of WT, $1 \mathrm{a}^{-1-}$, and $1 \mathrm{~b}^{-1-}$ mice $(8-12$ weeks old, $n=3$ per genotype) included the analysis of 10 different MF boutons per mouse. MF boutons were identified by their large size (3-6 $\mu \mathrm{m}$ in diameter), the dense packing with synaptic vesicles and their contacts with at least 2 spines. For each MF bouton we examined at least 4 consecutive sections. Only immunogold particles at the plasma membrane (closer than $20 \mathrm{~nm}$ ) of morphologically identifiable large MF boutons and their postsynaptic structures were analyzed. The postsynaptic distribution of $\mathrm{GABA}_{\mathrm{B} 1}$ protein relative to asymmetrical, putative glutamatergic synapses was determined by measuring the distance between each immunogold particle and the edge of the nearest synapse along the surface of spines. Immunogold particles were allocated to $60 \mathrm{~nm}$ wide bins, followed by calculating the relative abundance in each bin. The experimenter was blind to the genotype of the mice.

Immunoblot quantification. The ratio of $\mathrm{GABA}_{\mathrm{B} 1 \mathrm{a}}$ to $\mathrm{GABA}_{\mathrm{B} 1 \mathrm{~b}}$ protein in the $\mathrm{CA} 3$ region of the hippocampus was determined by immunoblot analysis using rabbit polyclonal $\mathrm{GABA}_{\mathrm{B} 1}$ antiserum $\mathrm{Ab} 174.1$ raised against the C-terminal domain of $\mathrm{GABA}_{\mathrm{B} 1 \mathrm{a}}$ and $\mathrm{GABA}_{\mathrm{B} 1 \mathrm{~b}}$ (Vigot et al., 2006). Scanned immunoblots were quantified using Scion Image software (Scion).

Slice preparation and electrophysiology. Hippocampal slices were prepared from 21- to 35-d-old mice using standard procedures (Vigot et al., 2006). Parasagittal slices (300 $\mu \mathrm{m}$ thick) were cut in ice-cold artificial CSF (ACSF) containing (in mM) $124 \mathrm{NaCl}, 2.7 \mathrm{KCl}, 1.3 \mathrm{MgCl}_{2}, 2 \mathrm{CaCl}_{2}$, $1.24 \mathrm{NaH}_{2} \mathrm{PO}_{4}, 26 \mathrm{NaHCO}_{3}, 18$ glucose, 2.25 ascorbate, $\mathrm{pH}$ 7.3, equilibrated with $95 \% \mathrm{O}_{2} / 5 \% \mathrm{CO}_{2}$. Slices were kept in oxygenated ACSF at $35^{\circ} \mathrm{C}$ for at least $45 \mathrm{~min}$ before recording. Visualized whole-cell patchclamp recording was used to investigate presynaptic and postsynaptic $\mathrm{GABA}_{\mathrm{B}}$ receptor functions. Holding currents and excitatory synaptic responses were recorded at $30-32^{\circ} \mathrm{C}$ from the somata of $\mathrm{CA} 3$ pyramidal neurons visualized using an infrared-sensitive camera (Till Photonics) and differential interference contrast optics (BX51WI; Olympus). Drugs were applied by superfusion into the recording chamber.

EPSCs were recorded with electrodes $(\sim 5 \mathrm{M} \Omega)$ filled with a solution containing (in mM): 140 Cs-gluconate, 10 HEPES, 10 phosphocreatine, 5 QX-314, 4 Mg-ATP, $0.3 \mathrm{Na}$-GTP, at pH 7.25 with CsOH, $285 \mathrm{mOsm}$. EPSCs were elicited by voltage pulses $(100 \mu \mathrm{s}, 2-5 \mathrm{~V}$ stimuli) delivered through a bipolar Pt-Ir electrode $(25 \mu \mathrm{m}$ in diameter) placed in the stratum lucidum. MF EPSCs were identified by the presence of a frequency-dependent short-term facilitation. EPSCs were measured at $-70 \mathrm{mV}$ in the presence of $100 \mu \mathrm{M}$ picrotoxin. Presynaptic $\mathrm{GABA}_{\mathrm{B}}$ and adenosine receptors were activated by bath application of baclofen ( 50 $\mu \mathrm{M})$ and adenosine $(100 \mu \mathrm{M})$, respectively. $\mathrm{GABA}_{\mathrm{B}}$ receptors were inhibited by application of the antagonist CGP54626A ( $1 \mu \mathrm{M})$. For the presynaptic dose-response experiments, baclofen at different concentrations $(0.1,1$ and $50 \mu \mathrm{M})$ was bath applied for $5 \mathrm{~min}$ at $10 \mathrm{~min}$ intervals.

To record postsynaptic Kir3-type $\mathrm{K}^{+}$currents, patch pipettes were filled with a solution containing (in $\mathrm{mm}$ ): $140 \mathrm{~K}$-gluconate, 5 HEPES, 2 $\mathrm{MgCl}_{2}, 1.1$ EGTA, $2 \mathrm{Na}_{2}$-ATP, 5 phosphocreatine, 0.6 Tris-GTP, at $\mathrm{pH}$ 7.25 with $\mathrm{KOH}, 285 \mathrm{mOsm}$. Kir3-type $\mathrm{K}^{+}$currents induced by baclofen $(100 \mu \mathrm{M})$ or adenosine $(100 \mu \mathrm{M})$ were elicited at $-50 \mathrm{mV}$ in the presence of tetrodotoxin (TTX, $1 \mu \mathrm{M}$ ). For concentration-response experiments we applied baclofen solutions $(0.3-100 \mu \mathrm{M})$ for $30 \mathrm{~s}$ using the fast gravitation driven application system WAS-02 (Dittert et al., 2006). The inner diameter of the application tube was $300 \mu \mathrm{m}$. The distance between the mouth of the tube and the soma of the neuron was $\sim 400 \mu \mathrm{m}$. $\mathrm{GABA}_{\mathrm{A}}$ - and $\mathrm{GABA}_{\mathrm{B}}$-mediated IPSCs (early and late IPSCs, respectively) were recorded with a solution containing (in $\mathrm{mM}$ ) $124 \mathrm{~K}$-gluconate, 16 $\mathrm{KCl}, 5 \mathrm{HEPES}, 2 \mathrm{MgCl}_{2}$, 1.1 EGTA, $2 \mathrm{MgATP}, 3 \mathrm{Na}_{3} \mathrm{GTP}$, pH 7.25. IPSCs were elicited at $-60 \mathrm{mV}$ by $100 \mu$ s pulses ( 3 stimuli at $100 \mathrm{~Hz}$ ) in the presence of kynurenic acid (2 mM), DNQX (10 $\mu \mathrm{M})$, naloxone $(10 \mu \mathrm{M})$ and 8-cyclopentyl-1,3-dipropylxanthine (DPCPX, $1 \mu \mathrm{M}$ ) to block glutamate, opioid and $\mathrm{A} 1$ adenosine receptors.

$\mathrm{GABA}_{\mathrm{B}}$-mediated heterosynaptic depression at MF synapses was studied by recording field EPSPs (fEPSPs) in the stratum lucidum (Vogt and Nicoll, 1999; Chandler et al., 2003). The occurrence of heterosynaptic depression is not critically dependent on the temperature, as no significant differences were previously observed between experiments at room temperature and at $34^{\circ}-36^{\circ} \mathrm{C}$ (Vogt and Nicoll, 1999). We therefore recorded fEPSPs at room temperature, using low resistance glass pipettes filled with ACSF. Stimulating electrodes filled with ACSF were positioned into the dentate gyrus, and MF responses elicited by $100 \mu$ s pulses. MF-evoked fEPSPs were identified through their characteristic shortterm plasticity and their sensitivity to the group II mGluR agonist (2S,2'R,3'R)-2-(2',3'-dicarboxycyclopropyl)-glycine (DCG-IV, $2 \mu \mathrm{M}$ ) (Kamiya et al., 1996). Heterosynaptic depression was measured in the presence of naloxone $(10 \mu \mathrm{M})$ and DPCPX $(1 \mu \mathrm{M})$ to avoid interference from presynaptic opioid and Al adenosine receptors, respectively (Weisskopf et al., 1993; Manzoni et al., 1994; Cunha, 2008). Under these con- 
ditions heterosynaptic depression was significantly reduced by the $\mathrm{GABA}_{\mathrm{B}}$ antagonist CGP54626A (2 $\left.\mu \mathrm{M}\right)$. Data were acquired with an Axopatch 200B (Molecular Devices), filtered at $2 \mathrm{kHz}$ and digitized at $10 \mathrm{kHz}$ using a Digidata 1322A Interface (Molecular Devices) driven by pClamp 9.2 software (Molecular Devices). Whole-cell currents and field potentials were analyzed using Clampfit 9.2 software (Molecular Devices). Baclofen and CGP54626A were from Novartis Pharma. Naloxone, DNQX, DPCPX, and DCG-IV were from Tocris Cookson, TTX from Latoxan. All other reagents were from Sigma-Aldrich. Most recordings were made and analyzed in blind. All values are means \pm SEM.

\section{Results}

Presynaptic versus postsynaptic distribution of $\mathrm{GABA}_{\mathrm{B} 1}$ isoforms at MF-CA3 pyramidal neuron synapses

Before addressing the contribution of $\mathrm{GABA}_{\mathrm{B}}$ receptor subtypes to presynaptic inhibition at MF terminals, we determined the $\mathrm{GABA}_{\mathrm{Bla}}$ and $\mathrm{GABA}_{\mathrm{B} 1 \mathrm{~b}}$ distribution at presynaptic and postsynaptic sites. We performed pre-embedding immunogold electron microscopy in the hippocampal CA3 stratum lucidum of WT, $1 \mathrm{a}^{-1-}$, and $1 \mathrm{~b}^{-1-}$ mice, using a pan $\mathrm{GABA}_{\mathrm{B} 1}$ antibody recognizing $\mathrm{GABA}_{\mathrm{B} 1 \mathrm{a}}$ and $\mathrm{GABA}_{\mathrm{B} 1 \mathrm{~b}}$. MF-CA3 pyramidal neuron synapses within large MF boutons were identified at the ultrastructural level as asymmetrical synapses at the spines of pyramidal neurons. In WT mice $\mathrm{GABA}_{\mathrm{B} 1}$ protein was present at presynaptic and postsynaptic elements of MF-CA3 pyramidal neuron synapses (Fig. $1 A-C$ ). $19.3 \pm 10.7 \%$ of all counted immunogold particles were localized at synaptic and extrasynaptic sites of MF boutons, while the remaining $80.7 \pm 10.7 \%$ were associated with spines and proximal dendritic shafts of pyramidal neurons (Fig. $1 J$ ). A similar distribution was reported for the MF-CA3 pyramidal neuron synapse in rat brain (Kulik et al., 2003). In $1 \mathrm{a}^{-1-}$ mice, $92.7 \pm 2.1 \%$ of all immunogold particles were observed on spines and dendritic shafts of pyramidal neurons, indicating that $\mathrm{GABA}_{\mathrm{B} 1 \mathrm{~b}}$ protein mainly localizes to postsynaptic elements (Fig. $1 D-F, J)$. In contrast, in $1 \mathrm{~b}^{-1-}$ mice $55.3 \pm 4.6 \%$ of all immunogold particles were associated with the presynaptic membrane of MF boutons, demonstrating that $\mathrm{GABA}_{\mathrm{Bla}}$ protein is slightly more abundant at presynaptic elements (Fig. $1 G-J$ ). Strikingly, the ratios of pre- to postsynaptic immunogold particles in the different genotypes were similar at MF-CA3 pyramidal neuron synapses (ratios for WT: $0.24,1 \mathrm{a}^{-1-}: 0.08,1 \mathrm{~b}^{-1-}: 1.24$ ) and CA3-CA1 synapses (ratios for WT: $0.31,1 \mathrm{a}^{-1-}: 0.17,1 \mathrm{~b}^{-1-}$ : 1.61; (Vigot et al., 2006)). Quantification from immunoblots indicates an overall $\mathrm{GABA}_{\mathrm{B} 1 \mathrm{a}}$ to $\mathrm{GABA}_{\mathrm{B} 1 \mathrm{~b}}$ protein ratio of $0.60 \pm$ 0.04 ( $n=4$ mice, $p<0.01$, one sample Student's $t$ test $)$ in the CA3 region of the hippocampus (data not shown). Considering this ratio and the synaptic distribution of immunogold particles, we approximately estimate that the $\mathrm{GABA}_{\mathrm{B} 1 \mathrm{a}}$ to $\mathrm{GABA}_{\mathrm{B} 1 \mathrm{~b}}$ protein ratio at presynaptic and postsynaptic sites is $4.5: 1$ and 1:3.5, respectively. Importantly, we did not observe any MF boutons and associated postsynaptic spines without specific immunogold particle labeling, suggesting that most, if not all, MF synapses express $\mathrm{GABA}_{\mathrm{B}}$ receptors.

\section{Subsynaptic distribution of $\mathrm{GABA}_{\mathrm{B} 1}$ isoforms in presynaptic and postsynaptic elements of MF-CA3 pyramidal neuron synapses}

We next studied the distribution of $\mathrm{GABA}_{\mathrm{B} 1}$ protein relative to synaptic specializations at MF-CA3 pyramidal neuron synapses. We first determined the percentage of $\mathrm{GABA}_{\mathrm{B} 1}$ immunogold particles in MF boutons that are present at presynaptic membranes opposite to postsynaptic densities (PSDs). In WT and $1 \mathrm{~b}^{-1-}$ mice $22 \%$ of all presynaptic $\mathrm{GABA}_{\mathrm{B} 1}$ immunogold particles were localized opposite to PSDs and 78\% at extrasynaptic membranes
(Fig. $2 A$ ). In $1 \mathrm{a}^{-1-}$ mice $11 \%$ of all immunogold particles in MF boutons were found opposite to PSDs, demonstrating that the $\mathrm{GABA}_{\mathrm{B} 1 \mathrm{~b}}$ protein distribution is significantly shifted toward extrasynaptic sites. Considering an overall $\mathrm{GABA}_{\mathrm{B} 1 \mathrm{a}}$ to $\mathrm{GABA}_{\mathrm{B} 1 \mathrm{~b}}$ protein ratio of 0.60 (see above), we approximately estimate a $\mathrm{GABA}_{\mathrm{Bla}}$ to $\mathrm{GABA}_{\mathrm{B} 1 \mathrm{~b}}$ protein ratio of 9:1 in the active zones of MF boutons. We additionally analyzed the distribution of $\mathrm{GABA}_{\mathrm{B} 1}$ protein in dendritic spines of CA3 pyramidal neurons. Independent of the genotype we rarely observed immunogold particles in the PSD, likely because the pre-embedding technique limits penetration of immunoreagents into the PSD (Kulik et al., 2002 , 2003). However, we did not observe any significant differences between $\mathrm{WT}, 1 \mathrm{a}^{-1-}$, and $1 \mathrm{~b}^{-/-}$mice in the distribution of $\mathrm{GABA}_{\mathrm{B} 1}$ immunoparticles at perisynaptic and extrasynaptic dendritic sites (Fig. 2 B). Of note, $\sim 20 \%$ of all immunoparticles were found within $60 \mathrm{~nm}$ from the edge of the PSDs at perisynaptic sites.

$\mathrm{GABA}_{\mathrm{B}(1 \mathrm{a}, 2)}$ receptors are more efficient than $\mathrm{GABA}_{\mathrm{B}(1 \mathrm{l}, 2)}$ receptors in inhibiting glutamate release in response to pharmacological activation

We used whole-cell patch-clamp recording in slice preparations from WT, $1 \mathrm{a}^{-1-}$, and $1 \mathrm{~b}^{-1-}$ mice to examine to what extent $\mathrm{GABA}_{\mathrm{B}(1 \mathrm{a}, 2)}$ and $\mathrm{GABA}_{\mathrm{B}(1 \mathrm{~b}, 2)}$ receptors can inhibit glutamate release in response to a maximally active concentration of the agonist baclofen. Stimulation of MFs in the stratum lucidum induces EPSCs in CA3 pyramidal neurons that are reduced in amplitude by activation of $\mathrm{GABA}_{\mathrm{B}}$ heteroreceptors. A high concentration of baclofen $(50 \mu \mathrm{M})$ reduced EPSC amplitudes in all three genotypes (Fig. $3 A, B$ ). However, baclofen was significantly less effective in inhibiting release in $1 \mathrm{a}^{-1-}$ mice than in WT and $1 \mathrm{~b}^{-/-}$mice. As a control, activation of adenosine Al receptors by adenosine inhibited glutamate release in all three genotypes to a similar extent (Fig. $3 A, B$ ). We tested whether lower concentrations of baclofen $(0.1,1 \mu \mathrm{M})$ activate $\mathrm{GABA}_{\mathrm{B}(1 \mathrm{a}, 2)}$ heteroreceptors without engaging $\mathrm{GABA}_{\mathrm{B}(1 \mathrm{~b}, 2)}$ heteroreceptors (Fig. $3 C$ ). This was the case at 0.1 $\mu \mathrm{M}$, at which concentration baclofen reduced glutamate release in WT and $1 \mathrm{~b}^{-1-}$ mice but not in $1 \mathrm{a}^{-1-}$ mice (Fig. 3C). Altogether, the electrophysiological data therefore parallel the ultrastructural data described above (Figs. 1,2). They support that the number of $\mathrm{GABA}_{\mathrm{B}(1 \mathrm{a}, 2)}$ heteroreceptors in $1 \mathrm{~b}^{-/-}$mice is sufficient to produce a maximal level of presynaptic inhibition (similar to $\mathrm{WT}$ ), while $\mathrm{GABA}_{\mathrm{B}(1 \mathrm{~b}, 2)}$ heteroreceptors in $1 \mathrm{a}^{-/-}$mice are limiting and consequently produce submaximal inhibition. At low concentrations of baclofen, only $\mathrm{GABA}_{\mathrm{B}(1 \mathrm{a}, 2)}$ heteroreceptors appear to be present in sufficient numbers to inhibit glutamate release.

Recent reports show that certain presynaptic $\mathrm{GABA}_{\mathrm{B}}$ receptors can be tonically activated by ambient GABA (Jensen et al., 2003; Lei and McBain, 2003; Liu et al., 2006). Bath application of the $\mathrm{GABA}_{\mathrm{B}}$ antagonist CGP54626A had no effect on the amplitudes of evoked EPSCs in WT, $1 \mathrm{a}^{-1-}$, and $1 \mathrm{~b}^{-1-}$ mice (Fig. $3 D, E)$. This demonstrates that under our experimental conditions ambient GABA does not tonically activate $\mathrm{GABA}_{\mathrm{B}}$ heteroreceptors at MF boutons.

$\mathrm{GABA}_{\mathrm{B}(1 \mathrm{a}, 2)}$ and $\mathrm{GABA}_{\mathrm{B}(1 \mathrm{~b}, 2)}$ receptors activate postsynaptic $\mathrm{K}^{+}$channels to a similar extent in response to pharmacological activation

We next studied the relative contributions of $\mathrm{GABA}_{\mathrm{Bla}}$ and $\mathrm{GABA}_{\mathrm{B} 1 \mathrm{~b}}$ isoforms to the formation of functional somatodendritic $\mathrm{GABA}_{\mathrm{B}}$ receptors on CA3 pyramidal neurons, using somatic whole-cell patch-clamp recordings in slices. Somatoden- 

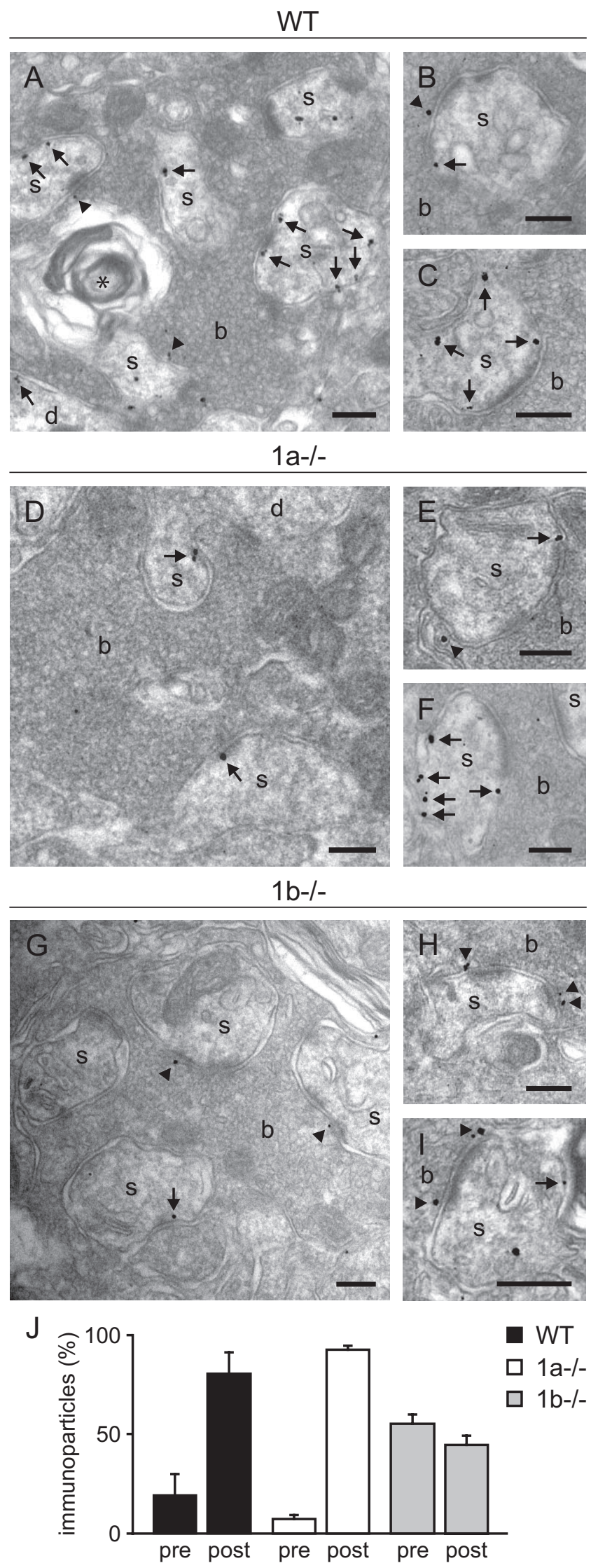

Figure 1. Electron micrographs showing the distribution of $G A B A_{B 1}$ immunogold particles at MF-CA3 pyramidal neuron synapses in the stratum lucidum. $A-C$, In WT mice, immunogold particles were predominantly detected on dendritic spines and shafts of pyramidal cells (arrows) as well as in MF boutons (arrowheads). Immunogold particles were frequently found at
A

Mossy fiber boutons

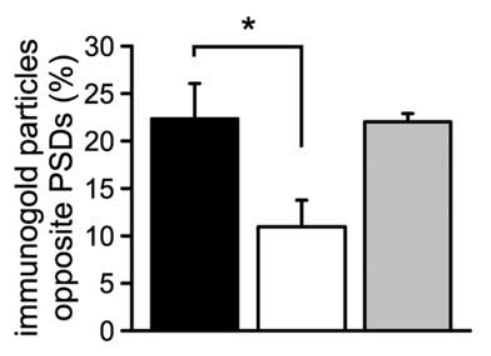

- WT

ㅁ $1 \mathrm{a}-/-$

$\square 1 \mathrm{~b}-/-$

B

Dendritic spines

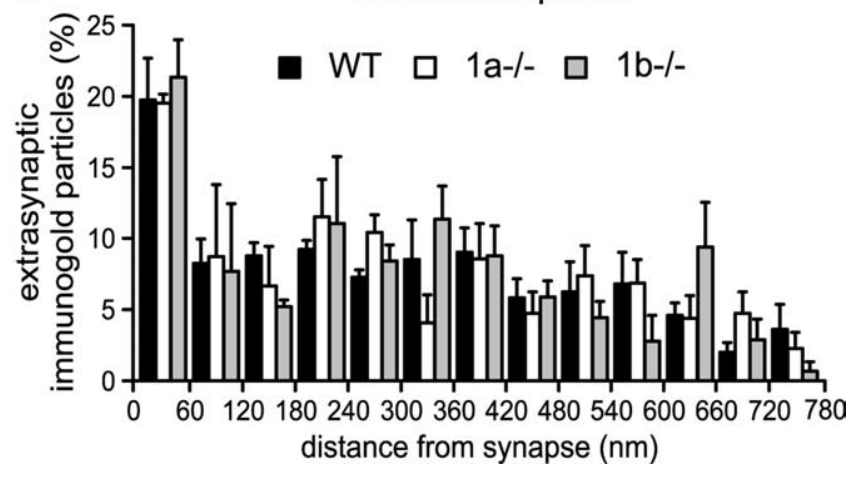

Figure 2. Distribution of $\mathrm{GABA}_{B 1}$ immunogold particles in presynaptic and postsynaptic elements of MF-CA3 pyramidal neuron synapses. $A$, Percentage of $G A B A_{B 1}$ immunogold particles at presynaptic membrane specializations of MF boutons opposite to PSDs (WT: $22.5 \pm$ $3.9 \% ; 1 \mathrm{a}^{-1-}: 11.1 \pm 2.8 \% ; 1 \mathrm{~b}^{-1-}: 22.2 \pm 0.8 \%, n=3,{ }^{*} p<0.05$, ANOVA/Dunnett's multiple comparison post hoc test). $B$, Histogram showing the spatial distribution of dendritic $G_{A B A_{B 1}}$ immunogold particles relative to the postsynaptic density. No significant differences between genotypes were detected. $G A B A_{B 1}$ immunogold particles were generally enriched in the perisynaptic region within $60 \mathrm{~nm}$ from the edge of the PSD. Values are means \pm SEM.

dritic $\mathrm{GABA}_{\mathrm{B}}$ receptors induce a late IPSC by activating Kir3-type $\mathrm{K}^{+}$channels (Lüscher et al., 1997). At a holding potential of -50 $\mathrm{mV}$ and at a physiological concentration of extracellular $\mathrm{K}^{+}$, pharmacological activation with a maximally active concentration of baclofen $(100 \mu \mathrm{M})$ elicited smaller outward $\mathrm{K}^{+}$currents in CA3 pyramidal cells of $1 \mathrm{a}^{-1-}$ and $1 \mathrm{~b}^{-1-}$ mice compared with WT mice (Fig. $4 A, B$ ). The maximal $\mathrm{K}^{+}$currents induced by baclofen were similar in $1 \mathrm{a}^{-1-}$ and $1 \mathrm{~b}^{-1-}$ mice, thus showing that $\mathrm{GABA}_{\mathrm{B}(1 \mathrm{~b}, 2)}$ and $\mathrm{GABA}_{\mathrm{B}(1 \mathrm{a}, 2)}$ receptors activate $\mathrm{K}^{+}$channels to a similar extent. Pharmacological activation of adenosine A1 receptors, which converge on the same Kir3-type $\mathrm{K}^{+}$channels (Lüscher et al., 1997), induced similar outward currents in all genotypes (Fig. 4A, B). This indicates that the expression levels of

\footnotetext{
$\leftarrow$

the edge of the presynaptic membrane specialization and at perisynaptic and extrasynaptic dendritic sites. $\boldsymbol{D}-\boldsymbol{F}$, In $1 \mathrm{a}^{-1-}$ mice, immunogold particles were almost exclusively found in postsynaptic elements, predominantly at perisynaptic and extrasynaptic sites. In rare cases, immunogold particles were also observed in MFboutons (E) $. \mathbf{G}-I, \ln 1 \mathrm{~b}^{-/-}$mice, immunogold particles were observed in presynaptic and postsynaptic elements. Immunogold particles were frequently found at the presynaptic membrane specialization of MF boutons. J, Quantitative analysis of presynaptic versus postsynaptic immunogold particles in WT, $1 \mathrm{a}^{-/-}$, and $1 \mathrm{~b}^{-/-}$ mice (percentage presynaptic particles: WT, $19.3 \pm 10.7 \% ; 1 \mathrm{a}^{-1-}, 7.3 \pm 2.1 \% ; 1 \mathrm{~b}^{-1-}$, $55.3 \pm 4.6 \% ; n=3$ mice per genotype). Immunogold particles were less frequent in $1 \mathrm{~b}^{-1-}$ compared with $1 \mathrm{a}^{-1-}$ and WT mice, which is reflected by the total number of particles that were analyzed (WT: $n=1570 ; 1 \mathrm{a}^{-1-}: n=1419 ; 1 \mathrm{~b}^{-1-}: n=1120$ ). b, MF bouton; $\mathrm{s}$, dendritic spine; $d$, dendritic shaft; asterisk, degenerated unmyelinated axon. Scale bars: 200 $\mathrm{nm}$. Values are means $\pm \mathrm{SD}$.
} 
Kir3-type $\mathrm{K}^{+}$channels are not altered as a consequence of the lack of $\mathrm{GABA}_{\mathrm{B} 1}$ isoform proteins. We tested whether lower concentrations of baclofen possibly generate distinct $\mathrm{K}^{+}$outward currents in $1 \mathrm{a}^{-1-}$ and $1 \mathrm{~b}^{-1-}$ mice, which was not the case (Fig. 4C). A reduction of $\mathrm{K}^{+}$current amplitudes in $1 \mathrm{a}^{-1-}$ and $1 \mathrm{~b}^{-1-}$ mice was only observed at high concentrations of baclofen $(100 \mu \mathrm{M})$, while at lower concentrations $(\leq 10 \mu \mathrm{M})$ the $\mathrm{K}^{+}$current amplitudes were similar in all genotypes (Fig. $4 C)$. Since at all concentrations of baclofen the $\mathrm{GABA}_{\mathrm{B}}$-induced $\mathrm{K}^{+}$currents in $1 \mathrm{a}^{-1-}$ and $1 \mathrm{~b}^{-1-}$ mice were similar, this suggests that $\mathrm{GABA}_{\mathrm{B}(1 \mathrm{~b}, 2)}$ and $\mathrm{GABA}_{\mathrm{B}(1 \mathrm{a}, 2)}$ receptors are able to activate $\mathrm{K}^{+}$channels to a similar extent.

$\mathrm{GABA}_{\mathrm{B}(1 \mathrm{a}, 2)}$ but not $\mathrm{GABA}_{\mathrm{B}(1 \mathrm{~b}, 2)}$ receptors inhibit glutamate release in response to physiological activation To address to what extent the two $\mathrm{GABA}_{\mathrm{B}}$ receptor subtypes contribute to physiological inhibition of glutamate release at MF terminals we examined heterosynaptic depression in WT, $1 \mathrm{a}^{-/-}$, and $1 \mathrm{~b}^{-/-}$mice. $\mathrm{GABA}_{\mathrm{B}}$ receptor-mediated heterosynaptic depression of MF transmission has been studied using fEPSP recordings and relies on the activation of $\mathrm{GABA}_{\mathrm{B}}$ heteroreceptors by GABA released from neighboring interneurons (Vogt and Nicoll, 1999; Chandler et al., 2003). We first verified that the stimulating electrode in the dentate gyrus evokes fEPSPs with properties consistent with MF transmission. MF synaptic responses were identified by the presence of paired-pulse facilitation, frequency-dependent short-term facilitation and sensitivity to the mGluR agonist DCG-IV, which blocks glutamate release from the MF but not from the associational-commissural fibers (Kamiya et al., 1996; Yeckel et al., 1999; Kirschstein et al., 2004; Nicoll and Schmitz, 2005). When fEPSPs were evoked with pairedpulse stimulation (100 ms apart), fEPSPs exhibited a pronounced facilitation of $197.4 \pm 14.6 \%$ ( $n=16$ slices $)$. In addition, when the stimulation frequency was increased from 0.05 to $1 \mathrm{~Hz}$, fEPSPs exhibited a marked frequency-dependent facilitation of $246.3 \pm 26.3 \%$ ( $n=8$ slices) (Fig. 5). Finally, as described (Kamiya et al., 1996; Yeckel et al., 1999), bath application of DCG-IV reduced the amplitude of fEPSPs measured at $0.05 \mathrm{~Hz}$ to $38.9 \pm 5.5 \%$ ( $n=9$ slices) (Fig. 5). Bath application of CGP54626A $(2 \mu \mathrm{M})$ had no significant effect on fEPSP peak amplitudes (control: $100 \pm 19.5 \%, n=7$ slices; CGP54626A: $98.9 \pm 18.3 \%, n=7$ slices), in keeping with patch-clamp experiments showing that ambient levels of GABA do not tonically activate $\mathrm{GABA}_{\mathrm{B}}$ heteroreceptors (Fig. 3D,E).
A
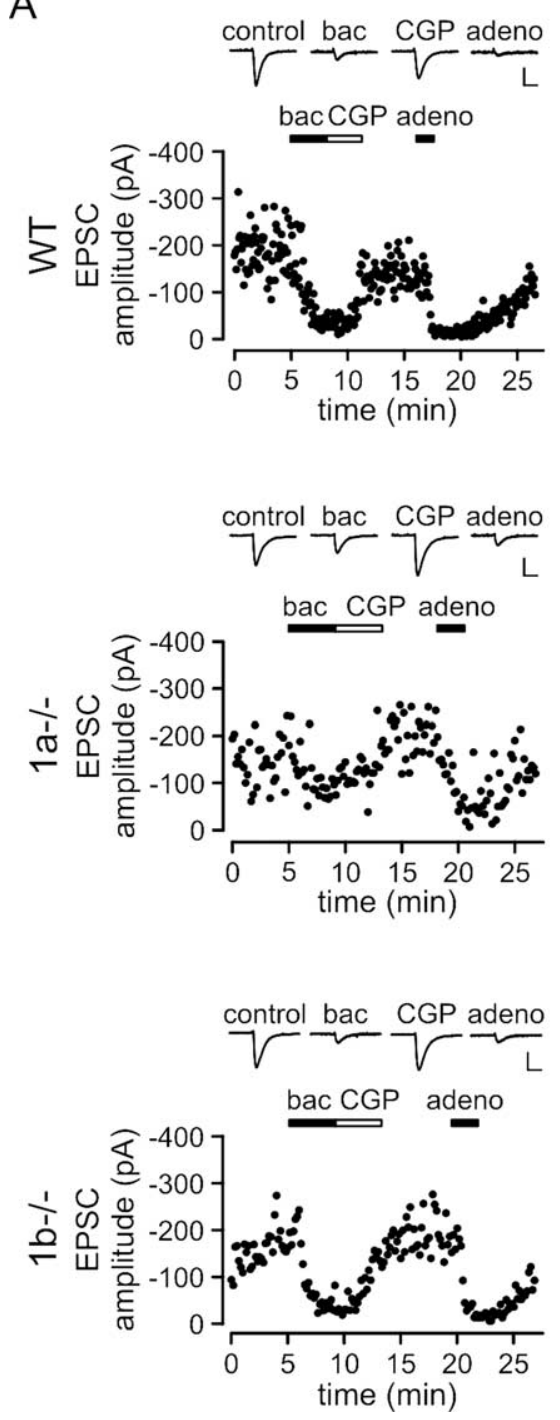

B

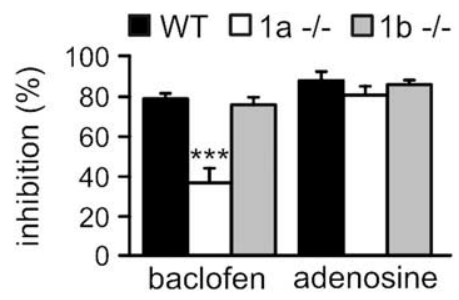

C

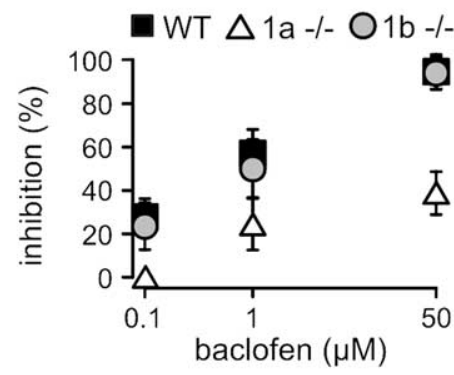

Figure 3. $G A B A_{B}$ heteroreceptor function at MF-CA3 pyramidal neuron synapses. $A, B$, EPSC peak amplitudes plotted versus time, average current traces, and summary histogram of monosynaptic EPSCs inhibition by baclofen (bac) and adenosine (adeno). Baclofen $(50 \mu \mathrm{M})$ depressed the amplitude of EPSCs to the same extent in WT and $1 \mathrm{~b}^{-/-}$mice, but was less effective in $1 \mathrm{a}^{-/-}$ mice (WT: $78.6 \pm 2.6 \%$ inhibition, $n=7 ; 1 \mathrm{~b}^{-1-}: 75.6 \pm 3.7 \%$ inhibition, $n=6 ; 1 \mathrm{a}^{-1-}: 36.4 \pm 7.3 \%$ inhibition, $n=10$, ${ }^{* * *} p<0.001,1 \mathrm{a}^{-1-}$ compared with WT and $1 \mathrm{~b}^{-1-}$, ANOVA/Scheffe post hoc test). The inhibitory effect of baclofen was blocked by the $\mathrm{GABA}_{\mathrm{B}}$ receptor antagonist CGP54626A (CGP, $\left.1 \mu \mathrm{M}\right)$. As a control, adenosine $(100 \mu \mathrm{M})$ efficiently reduced the peak amplitudes of EPSCs in all genotypes (WT: $87.7 \pm 1.6 \%$ inhibition, $n=6 ; 1 \mathrm{a}^{-1-}: 80.4 \% \pm 4.4 \%$ inhibition, $n=8 ; 1 \mathrm{~b}^{-1-}$. $85.7 \pm 2.2 \%$ inhibition, $n=4$ ). Current traces in $A$ show averages of 10 successive EPSCs (calibration: $20 \mathrm{~ms} / 100 \mathrm{pA}$ ). C, Inhibition of glutamate release by different concentrations of baclofen. In $1 \mathrm{a}^{-1-}$ mice, baclofen was ineffective in inhibiting glutamate release at $0.1 \mu \mathrm{m}(n=5)$. At higher concentrations, baclofen was always less effective in inhibiting glutamate release in $1 \mathrm{a}^{-1-}$ mice compared with WT or $1 \mathrm{~b}^{-1-}$ mice $\left(1 \mu \mathrm{m}, 1 \mathrm{a}^{-1-}: 24 \pm 8.3 \%\right.$ inhibition, $n=5,{ }^{*} p<0.05,1 \mathrm{a}^{-1-}$ compared with WT and $1 \mathrm{~b}^{-/-} ; 50 \mu \mathrm{M}, 1 \mathrm{a}^{-/-}: 38.4 \pm 6.6 \%$ inhibition, $n=5,{ }^{* * *} p<0.001,1 \mathrm{a}^{-1-}$ compared with WT and $1 \mathrm{~b}^{-1-}$, ANOVA/Scheffe post hoc test). In WT and $1 \mathrm{~b}^{-1-}$ mice, baclofen reduced the peak amplitude of EPSCs to the same extent at $0.1 \mu \mathrm{m}$ (WT: $26.5 \pm$ 3.4\% inhibition, $n=4 ; 1 \mathrm{~b}^{-1-}: 23.4 \pm 6.1 \%$ inhibition, $n=4$ ), $1 \mu \mathrm{M}$ (WT: $57.2 \pm 5.6 \%$ inhibition, $n=4 ; 1 \mathrm{~b}^{-1-}: 50.1 \pm$ 8.9\% inhibition, $n=4$ ), and $50 \mu \mathrm{M}$ (WT: $94.8 \pm 2.6 \%$ inhibition, $n=4 ; 1 \mathrm{~b}^{-1-}: 94.2 \pm 2.2 \%$ inhibition, $\left.n=4\right)$ ). D, E, Lack of evidence for a tonic activity of GABA heteroreceptors at MF boutons. D, Evoked EPSCS of a WT CA3 pyramidal neuron recorded in the absence and presence of CGP54626A (1 $\mu \mathrm{M})$. $\boldsymbol{E}$, Summary histogram showing that in all genotypes the peak amplitudes of evoked EPSCs are not significantly altered in the presence of CGP54626A (WT: $98.2 \pm 4.5 \%, n=6 ; 1 \mathrm{a}^{-1-}: 100.9 \pm 9.0 \%, n=$ $\left.6 ; 1 \mathrm{~b}^{-1-}: 102.8 \pm 6.1 \%, n=5\right)$. Values are means \pm SEM.

To induce heterosynaptic depression at MF synapses we placed a second stimulating electrode into the dentate gyrus. The position of this electrode and the stimulus intensity were adjusted such that two independent MF pathways could be stimulated (Fig. 6A). Pathway one was stimulated at a regular interval of $10 \mathrm{~s}$ to evoke MF test fEPSPs (S1). Every tenth stimulus was preceded 
A
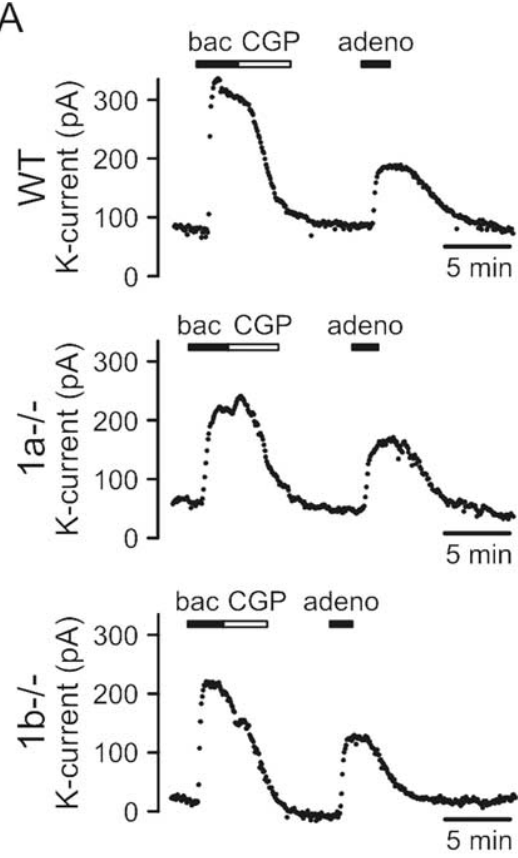

B

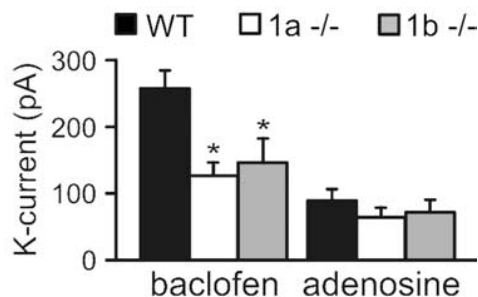

C

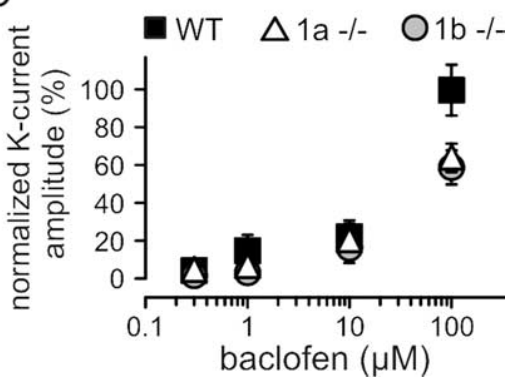

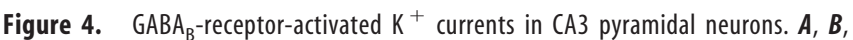
Changes in the holding current of CA3 pyramidal neurons following bath application of baclofen (bac; $100 \mu \mathrm{m}$ ) or adenosine (adeno; $100 \mu \mathrm{M}$ ) and summary histogram of the amplitude of baclofen- and adenosine-induced $\mathrm{K}^{+}$currents. The baclofen-induced outward $\mathrm{K}^{+}$current was blocked by CGP54626A (CGP; $\left.1 \mu \mathrm{M}\right)$ and significantly reduced in $1 \mathrm{a}^{-1-}$ and $1 \mathrm{~b}^{-1-}$ mice compared with WT mice (WT: $255.9 \pm 23.8 \mathrm{pA}, n=6 ; 1 \mathrm{a}^{-1-}$ : $112.8 \pm 17.5 \mathrm{pA}, n=7 ; 1 \mathrm{~b}^{-1-}: 130.3 \pm 31.9 \mathrm{pA}, n=7 ;{ }^{*} p<0.05,1 \mathrm{a}^{-1-}$ and $1 \mathrm{~b}^{-1-}$ compared with WT, ANOVA/Scheffe post hoc test). Control adenosine-induced $\mathrm{K}^{+}$currents were similar in all genotypes (WT: $79.4 \pm 15.2 \mathrm{pA}, n=6 ; 1 \mathrm{a}^{-I-}: 57.1 \pm 12.7 \mathrm{pA}$, $\left.n=7 ; 1 \mathrm{~b}^{-1-}: 64.0 \pm 16.5 \mathrm{pA}, n=7\right)$, showing that effector $\mathrm{K}^{+}$channels are not altered in $1 \mathrm{a}^{-I-}$ and $1 \mathrm{~b}^{-I-}$ mice. C, Normalized $\mathrm{K}^{+}$current amplitudes in response to increasing concentrations of baclofen. The maximal $\mathrm{K}^{+}$current amplitude for each concentration was normalized to the mean maximal $\mathrm{K}^{+}$current amplitude recorded from WT neurons at a saturating concentration of baclofen $(100 \mu \mathrm{M})$. In $1 \mathrm{a}^{-/-}$and $1 \mathrm{~b}^{-1-}$ mice, the amplitude of baclofen-induced $\mathrm{K}^{+}$was significantly reduced compared with WT mice at $100 \mu \mathrm{M}$ (WT: $100 \pm 13.6 \%, n=5 ; 1 \mathrm{a}^{-I-}: 63.7 \pm 7.7 \%, n=8 ; 1 \mathrm{~b}^{-1-}: 58.7 \pm$ $9.1 \%, n=5 ;{ }^{*} p<0.05,1 \mathrm{a}^{-1-}$ and $1 \mathrm{~b}^{-1-}$ compared with WT, ANOVA/Scheffe post hoc test). Baclofen-induced $\mathrm{K}^{+}$current amplitudes were not statistically different between genotypes at concentrations of $0.3 \mu \mathrm{M}$ (WT: $3.6 \pm 0.9 \%, n=5 ; 1 \mathrm{a}^{-1-}: 3.6 \pm 0.6 \%$, $\left.n=4 ; 1 \mathrm{~b}^{-l-}: 0.8 \pm 0.2 \%, n=4\right), 1 \mu \mathrm{M}$ (WT: $7.4 \pm 2 \%, n=5 ; 1 \mathrm{a}^{-/-}: 5.7 \pm 1.1 \%$, $\left.n=5 ; 1 \mathrm{~b}^{-l-}: 2.4 \pm 0.8 \%, n=4\right)$, and $10 \mu \mathrm{M}$ (WT: $21.7 \pm 3.5 \%, n=5 ; 1 \mathrm{a}^{-l-}$ : $\left.19.5 \pm 3.4 \%, n=6 ; 1 \mathrm{~b}^{-1-}: 15.5 \pm 2.9 \%, n=5\right)$. Values are means \pm SEM.
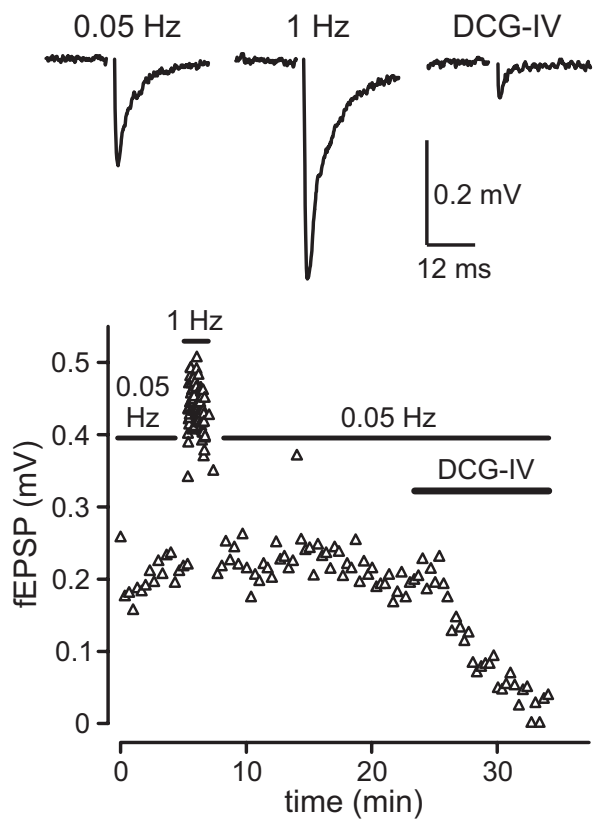

Figure 5. MF fEPSPs exhibit frequency-dependent short-term facilitation and sensitivity to the mGluR agonist DCG-IV. Average traces of fEPSPs recorded in the stratum lucidum at $0.05 \mathrm{~Hz}$ and $1 \mathrm{~Hz}$ and in the presence of DCG-IV (top) as well as amplitudes of fEPSPs plotted versus time (bottom) are shown. Increasing the stimulus frequency from 0.05 to $1 \mathrm{~Hz}$ induced pronounced facilitation. Bath application of DCG-IV $(2 \mu \mathrm{M})$ strongly inhibited fEPSP amplitudes elicited at $0.05 \mathrm{~Hz}$.

by a conditioning train of 20 stimuli at $100 \mathrm{~Hz}$ on pathway two (S2). The two pathways were stimulated $200 \mathrm{~ms}$ apart. To prevent interference from presynaptic opioid and Al adenosine receptors, heterosynaptic depression was measured in the presence of the antagonists naloxone and DPCPX. Under these conditions a marked $\mathrm{GABA}_{\mathrm{B}}$ receptor-mediated heterosynaptic depression is observed; only at stronger MF activation levels a direct activation of presynaptic mGluRs through spillover of glutamate will occur (Vogt and Nicoll, 1999). In WT mice, the amplitudes of test fEPSPs evoked after a train on pathway two (conditioned fEPSPs, closed circles) were significantly reduced by $25.7 \pm 3.3 \%$ ( $p<$ $0.01, n=6$ slices) compared with fEPSPs measured in the absence of a conditioning train (unconditioned fEPSPs) (Fig. 6B,E, open circles). CGP54626A largely or totally inhibited the reduction of conditioned fEPSP amplitudes (Fig. $6 B, E$ ), confirming that heterosynaptic depression was mainly mediated by $\mathrm{GABA}_{B}$ receptors. No $\mathrm{GABA}_{\mathrm{B}}$-mediated heterosynaptic depression was detectable in $1 \mathrm{a}^{-1-}$ mice (conditioned fEPSPs reduced by $2.5 \pm 1.4 \%$, $p=0.20, n=6$ slices) and accordingly, CGP54626A had no effect on fEPSPs (Fig. 6C,E). In contrast, we observed a significant heterosynaptic depression in $1 \mathrm{~b}^{-1-}$ mice (conditioned fEPSP amplitudes reduced by $26.2 \pm 2.8 \%, n=7$ slices; $p<0.001$ ), which was markedly reduced or abolished by CGP54626A (Fig. 6D,E). Confirming that our recordings relate to MF transmission, fEPSPs were always inhibited by application of DCG-IV (Fig. 6B-D). Of note, the amplitudes of unconditioned fEPSPs in WT and $1 \mathrm{~b}^{-1-}$ mice were increased in the presence of CGP54626A (Fig. $6 B, D$, open circles), suggesting that the GABA released by the conditioning train lasts long enough to significantly inhibit unconditioned fEPSPs during the 90 s preceding the next conditioning train. In support of this, we found that CGP54626A was without effect on unconditioned fEPSP amplitudes in the absence of the conditioning train (control: $100 \pm 18.6 \%, n=8$ slices; CGP54626A: $100.8 \pm 19.1 \%, n=8$ slices). CGP54626A had no 
A

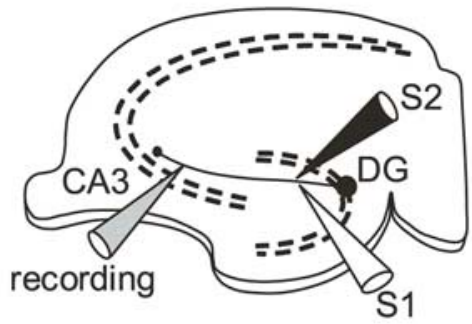

B
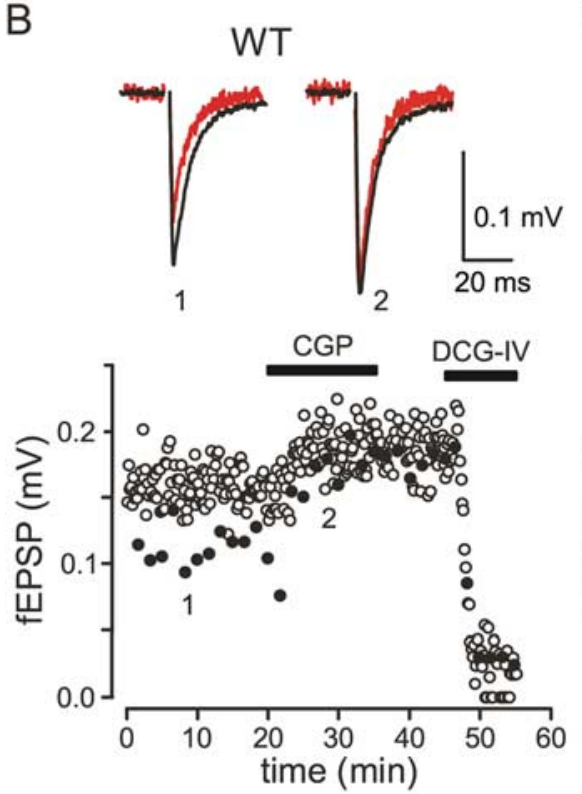

D
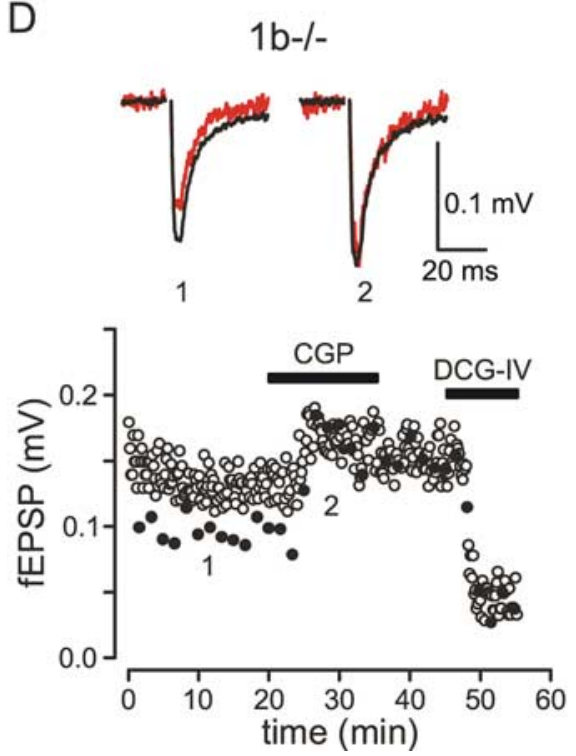

$E$
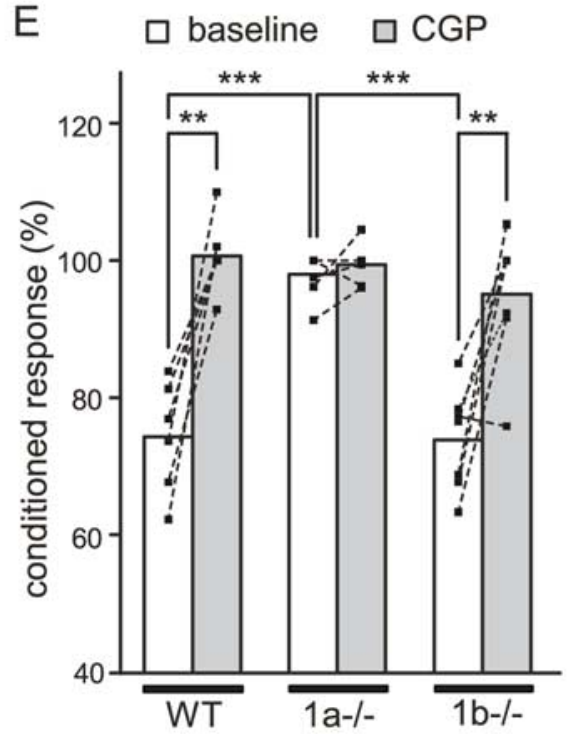

Figure 6. $\mathrm{GABA}_{\mathrm{B}}$-mediated heterosynaptic depression at MF-CA3 pyramidal neuron synapses. $\boldsymbol{A}$, Two electrodes $(\mathrm{S} 1, \mathrm{~S} 2)$ positioned in the dentate gyrus were used to stimulate two independent pathways. A third electrode in the $C A 3$ stratum lucidum was used to record MF fEPSPS. Pathway 1 was stimulated at a regular interval of $10 \mathrm{~s}$ to evoke test fEPSPs (S1, unconditioned response). Pathway 2 was stimulated $200 \mathrm{~ms}$ before every tenth test stimulus with a train of 20 stimuli at $100 \mathrm{~Hz}$ (S2, conditioned responses). $\boldsymbol{B}, G A B A_{B}$-mediated heterosynaptic depression in slices of WT mice. The amplitudes of fEPSPs plotted over time (bottom) and average traces (top) are shown. The amplitudes of fEPSPs preceded by a train (closed circles, red traces) were reduced compared with those of fEPSPs not preceded by a train (open circles, black traces). Heterosynaptic depression was largely inhibited or lost in the presence of (GP54626A (CGP; $2 \mu \mathrm{M})$. Average fEPSP traces are shown in the absence (1) and the presence (2) of (GP54626A (stimulation artifacts were removed). C, $G A B A_{B}$-mediated heterosynaptic depression was absent in slices of $1 \mathrm{a}^{-1-}$ mice. The amplitudes of conditioned fEPSPs were similar to those of unconditioned fEPSPS. D, GABA ${ }_{B}$-mediated heterosynaptic depression in slices of $1 \mathrm{~b}^{-1-}$ mice was similar to that in WT mice and inhibited by CGP54626A. Note that CGP54626A also increased the amplitude of unconditioned fEPSPs in WT and $1 \mathrm{~b}^{-/-}$mice but not in $1 \mathrm{a}^{-1-}$ mice $(\boldsymbol{B}-\boldsymbol{D})$. In all genotypes, fEPSPs were inhibited by DCG-IV $(2 \mu \mathrm{M})$. $\boldsymbol{E}$, Summary histogram of $G_{A B A_{B}}$-mediated heterosynaptic depression. The amplitudes effect on unconditioned fEPSP amplitudes in $1 \mathrm{a}^{-1-}$ mice, in agreement with a lack of functional $\mathrm{GABA}_{\mathrm{B}}$ heteroreceptors in these mice (Fig. 6C). In summary, our experiments show that exclusively $\mathrm{GABA}_{\mathrm{B}(1 \mathrm{a}, 2)}$ receptors mediate heterosynaptic depression at MF-CA3 synapses.

\section{Late IPSCs are detectable in WT mice} but not in $1 \mathrm{a}^{-/-}$and $1 \mathrm{~b}^{-/-}$mice $\mathrm{GABA}_{\mathrm{B}(1 \mathrm{a}, 2)}$ and $\mathrm{GABA}_{\mathrm{B}(1 \mathrm{~b}, 2)}$ receptors produce $\mathrm{K}^{+}$-currents of similar amplitude in response to pharmacological activation with baclofen (Fig. 4). However, it remains possible that $\mathrm{GABA}_{\mathrm{B}(1 \mathrm{a}, 2)}$ and $\mathrm{GABA}_{\mathrm{B}(1 \mathrm{~b}, 2)}$ receptors produce distinct postsynaptic responses following physiological activation, due to local differences in their somatodendritic abundance. In the hippocampus, synaptically released GABA induces $\mathrm{Cl}^{-}$-dependent early IPSCs and $\mathrm{K}^{+}$dependent late IPSCs that are mediated by $\mathrm{GABA}_{\mathrm{A}}$ and $\mathrm{GABA}_{\mathrm{B}}$ receptors, respectively (Misgeld et al., 1995; Lüscher et al., 1997). We simultaneously recorded early and late IPSCs in WT, $1 \mathrm{a}^{-/-}$, and $1 \mathrm{~b}^{-1-}$ mice. The early IPSC allowed us to verify that stimulation of the MF pathway provoked GABA release in all of our recordings. The amplitude of the late IPSC was used to quantify the extent of $\mathrm{GABA}_{\mathrm{B}}$ receptor activation in response to synaptically released GABA. Three stimuli at 100 $\mathrm{Hz}$ reliably evoked early and late IPSCs in WT mice. The occurrence of late IPSCs was prevented in the presence of CGP54626A, confirming that the late IPSCs are mediated by $\mathrm{GABA}_{\mathrm{B}}$ receptors (Fig. $7 A, D$ ). No late IPSCs were detectable in $1 \mathrm{a}^{-1-}$ and $1 \mathrm{~b}^{-1-}$ mice, although early IPSCs were always induced (Fig. $7 B-D$ ). This suggests that the reduction of functional postsynaptic $\mathrm{GABA}_{\mathrm{B}}$ receptors seen in $1 \mathrm{a}^{-1-}$ and $1 \mathrm{~b}^{-1-}$ mice after pharmacological stimulation (Fig. 4) leads to subthreshold late IPSCs under physiological conditions.

$\leftarrow$

of conditioned fEPSPs were normalized to amplitudes of unconditioned fEPSPs in the absence (baseline) and presence of CGP54626A. Significant CGP54626A-sensitive heterosynaptic depression was observed in WT mice (baseline: $74.3 \pm 4 \%$, $n=6$ slices; (GP54626A: $100.8 \pm 2.7 \%, n=6$ slices; $^{* * *} p<$ 0.01 , two-tailed paired Student's $t$ test) and $1 \mathrm{~b}^{-1-}$ mice (baseline: $73.8 \pm 2.8 \%, n=7$ slices; CGP54626A: $95 \pm$ $3.7 \%, n=7$ slices; ${ }^{* *} p<0.01$ ) but not in $1 \mathrm{a}^{-1-}$ mice (baseline: $97.5 \pm 1.4 \%, n=6$ slices; CGP54626A: $99.4 \pm$ $1.3 \%, n=6$ slices; $p=0.32$ ). The ANOVA/Scheffe post hoc test was used for the comparison of genotypes $\left({ }^{* * *} p<\right.$ 0.001 , normalized conditioned fEPSPs in $1 \mathrm{a}^{-1-}$ compared with WT and $1 b^{-1-}$ mice). Values are means \pm SEM. 
A

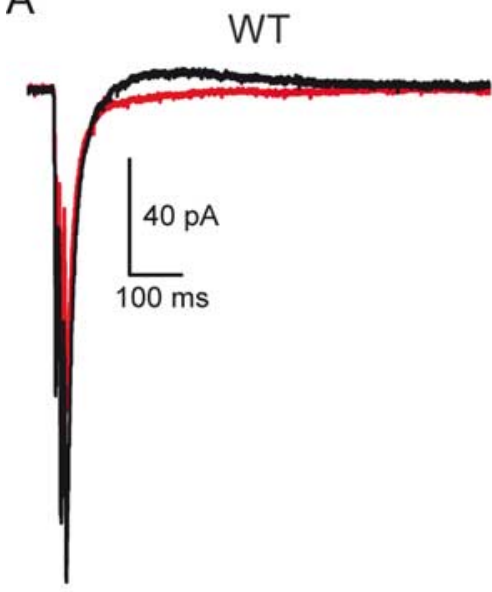

B

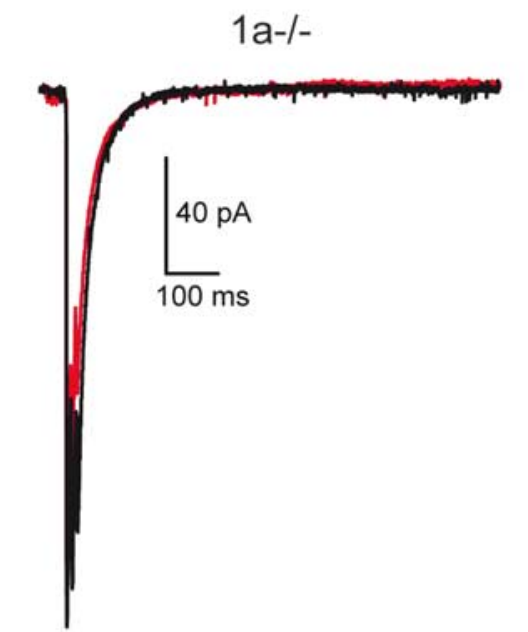

C

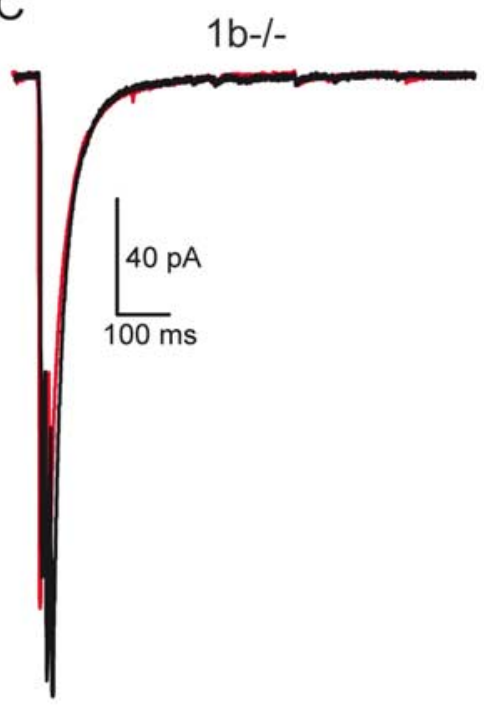

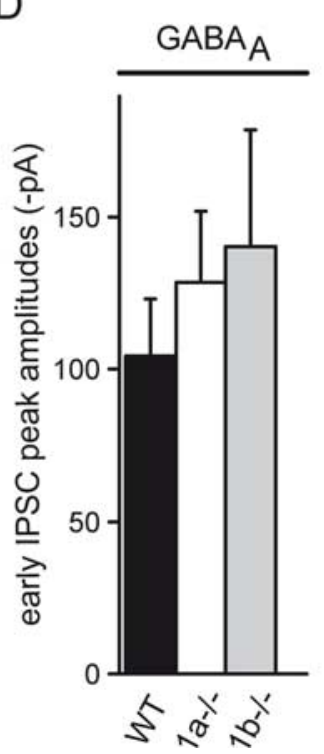

uted to axonal and dendritic compartments (Vigot et al., 2006). On the other hand, the expression of $\mathrm{GABA}_{\mathrm{B} 1 \mathrm{a}}$ and $\mathrm{GABA}_{\mathrm{B} 1 \mathrm{~b}}$ subunits is under separate transcriptional control, which will influence the ratio of receptor subtypes in individual neurons (Steiger et al., 2004). It seems reasonable to propose that separate control of both transcription and distribution of $\mathrm{GABA}_{\mathrm{B}}$ receptor subtypes has evolved to provide neurons with a means to independently adjust signaling at select effector systems. To support this concept, it is important to directly demonstrate that endogenously released GABA can differentially activate $\mathrm{GABA}_{\mathrm{B}}$ receptor subtypes (Huang, 2006). This is the case for inhibitory synapses at cortical layer 5 pyramidal neurons, where under physiological conditions selectively $\mathrm{GABA}_{\mathrm{B}(1 \mathrm{a}, 2)}$ and $\mathrm{GABA}_{\mathrm{B}(1 \mathrm{~b}, 2)}$ receptors act as autoreceptors and postsynaptic receptors, respectively (Pérez-Garci et al., 2006). Here, we addressed whether this is also the case for $\mathrm{GABA}_{\mathrm{B}}$ heteroreceptors at glutamatergic synapses. A physiological phenomenon that is reported to depend on the endogenous activation of $\mathrm{GABA}_{\mathrm{B}}$ heteroreceptors is heterosynaptic depression (Isaacson et al., 1993; Vogt and Nicoll, 1999; Chandler et al., 2003). We therefore determined the individual contributions of the two $\mathrm{GABA}_{\mathrm{B}}$ receptor subtypes to heterosynaptic depression at MF-CA3 pyramidal neuron synapses, where this phenomenon can be easily studied (Vogt and Nicoll, 1999; Chandler et al., 2003). Our data show that exclusively $\mathrm{GABA}_{\mathrm{B}(\mathrm{1a}, 2)}$ heteroreceptors mediate heterosynaptic depression of MF transmission. Yet the presence of functional $\mathrm{GABA}_{\mathrm{B}(1 \mathrm{~b}, 2)}$ heteroreceptors at $\mathrm{MF}$ boutons can be demonstrated in pharmacological experiments, in which concentrations of baclofen $\geq 1 \mu \mathrm{M}$ produce a component of presynaptic inhibition mediated by $\mathrm{GABA}_{\mathrm{B}(1 \mathrm{~b}, 2)}$ receptors. In pharmacological experiments, a selective presynaptic inhibition via $\mathrm{GABA}_{\mathrm{B}(1 \mathrm{a}, 2)}$ heteroreceptors was only observed at a lower concentration of baclofen $(0.1 \mu \mathrm{M})$. The most parsimonious explanation for these data is that the number of $\mathrm{GABA}_{\mathrm{B}(1 \mathrm{~b}, 2)}$ receptors at presynaptic sites in $1 \mathrm{a}^{-1-}$ mice is sufficient to measurably inhibit glutamate release in response to pharmacological activation with moderate to high concentrations of baclofen, but not to inhibit release in response to low concentrations of spillover GABA from neighboring interneurons. This may be accentuated by the fact that presynaptic $\mathrm{GABA}_{\mathrm{B}}$ receptors at MF boutons display non-desensitizing properties (Tosetti et al., 2004), which will render sustained pharmacological inhibition particularly effective. Baclofen likely also activates somatic $\mathrm{GABA}_{\mathrm{B}(1 \mathrm{~b}, 2)}$ receptors in the dentate granule cells. The ensuing hyperpolarizing potentials may passively propagate to the MF boutons and contribute to presynaptic inhibition (Alle and Geiger, 2006). The 
exact reason for presynaptic inhibition following pharmacological activation with baclofen is unknown. However, our results support that the spatial segregation of $\mathrm{GABA}_{\mathrm{B} 1}$ isoforms at $\mathrm{MF}$ terminals is sufficient to produce a strictly subtype-specific heteroreceptor response under physiological conditions. At other glutamatergic synapses baclofen also produces a significant level of presynaptic inhibition through $\mathrm{GABA}_{\mathrm{B}(1 \mathrm{~b}, 2)}$ heteroreceptors (Shaban et al., 2006; Vigot et al., 2006; Ulrich et al., 2007). We expect that under physiological conditions exclusively $\mathrm{GABA}_{\mathrm{B}(1 \mathrm{a}, 2)}$ receptors mediate heteroreceptor function at those synapses as well.

Heterosynaptic depression at MF-CA3 pyramidal neuron synapses is thought to play an important role in regulating mnemonic processes (Jin and Chavkin, 1999; Vogt and Nicoll, 1999; Vida and Frotscher, 2000; Chandler et al., 2003). Heterosynaptic depression increases the sparseness of input signals to CA3 pyramidal cells, thereby enhancing the storage capacity of the CA3 network. Overt memory deficits in hippocampus-dependent memory tasks in $1 \mathrm{a}^{-1-}$ mice (Vigot et al., 2006; Jacobson et al., 2007) may therefore relate, at least in part, to the disinhibition of $\mathrm{MF}$ inputs and the ensuing failure to store or recall memory traces. In addition, the control of $\mathrm{GABA}_{\mathrm{Bla}}$-mediated inhibition at MF boutons may be important for regulating synaptic plasticity and limbic seizure prevention, since these processes were also shown to be controlled by $\mathrm{GABA}_{\mathrm{B}}$ heteroreceptors (Vogt and Nicoll, 1999; Chandler et al., 2003).

We found that baclofen induces similar maximal $\mathrm{K}^{+}$currents in CA3 neurons of $1 \mathrm{a}^{-1-}$ and $1 \mathrm{~b}^{-1-}$ mice. Given the surplus of $\mathrm{GABA}_{\mathrm{B} 1 \mathrm{~b}}$ protein at dendritic sites opposite to MF terminals, it may appear surprising that the maximal $\mathrm{K}^{+}$currents induced by $\mathrm{GABA}_{\mathrm{B}(1 \mathrm{~b}, 2)}$ receptors are not larger than those induced by $\mathrm{GABA}_{\mathrm{B}(1 \mathrm{a}, 2)}$ receptors. However, caution should be exerted when comparing the ultrastructural data with the electrophysiological data. On the one hand, the $\mathrm{GABA}_{\mathrm{B}}$ receptors included in the ultrastructural analysis may not necessarily be coupled to $\mathrm{K}^{+}$ channels. For example, it is conceivable that a larger fraction of $\mathrm{GABA}_{\mathrm{B}(1 \mathrm{a}, 2)}$ receptors is colocalized with Kir3-type $\mathrm{K}^{+}$channels, rendering their coupling to effector channels more efficient (Karschin, 1999). Future studies, for example using high-resolution immunocytochemical techniques (Kulik et al., 2006), will have to address whether $\mathrm{GABA}_{\mathrm{B} 1}$ isoforms exhibit differences in the colocalization with Kir3-type $\mathrm{K}^{+}$channel subunits. On the other hand, baclofen probably mostly activates $\mathrm{K}^{+}$currents via somatodendritic $\mathrm{GABA}_{\mathrm{B}}$ receptors remote from MF synapses, and these receptors were excluded from the ultrastructural analysis. It is possible that the relative abundance of $\mathrm{GABA}_{\mathrm{B}(1 \mathrm{a}, 2)}$ and $\mathrm{GABA}_{\mathrm{B}(1 \mathrm{~b}, 2)}$ receptors differs between dendritic spines and shafts, similar as observed in CA1 pyramidal neurons where $\mathrm{GABA}_{\mathrm{B} 1 \mathrm{a}}$ protein does not efficiently enter the spines (Vigot et al., 2006). It further could be argued that the downregulation of $\mathrm{GABA}_{\mathrm{B} 1 \mathrm{a}}$ protein levels during early postnatal development (Malitschek et al., 1998; Fritschy et al., 1999) accounts for the difference between the morphological and electrophysiological data. However, ruling out this possibility, all our experiments were performed with mice 3 weeks of age or older, when $\mathrm{GABA}_{\mathrm{B} 1 \mathrm{a}}$ and $\mathrm{GABA}_{\mathrm{B} 1 \mathrm{~b}}$ protein levels remain stable (Malitschek et al., 1998). While many factors can contribute to the difference between the ultrastructural data of spines and the electrophysiological responses recorded for the soma of CA3 pyramidal neurons, our data further consolidate that the relative contributions of $\mathrm{GABA}_{\mathrm{Bla}}$ and $\mathrm{GABA}_{\mathrm{B} 1 \mathrm{~b}}$ subunits to the pool of $\mathrm{GABA}_{\mathrm{B}}$ receptors coupled to effector $\mathrm{K}^{+}$channels varies in between neurons (Ulrich and Bettler, 2007). Importantly, a physiological activation of somatoden- dritic $\mathrm{GABA}_{\mathrm{B}}$ receptors by synaptically released $\mathrm{GABA}$ does not produce a segregation of $\mathrm{GABA}_{\mathrm{B}(1 \mathrm{a}, 2)}$ and $\mathrm{GABA}_{\mathrm{B}(1 \mathrm{~b}, 2)}$ responses in CA3 pyramidal neurons, in contrast to the findings with cortical neurons (Huang, 2006; Pérez-Garci et al., 2006).

In conclusion, our results are consistent with the proposal that independent regulation of expression and distribution of $\mathrm{GABA}_{\mathrm{B}}$ receptor subtypes enables neurons to dynamically adjust $G_{A B} A_{B}$ signaling at axonal and dendritic effectors. The observation that $\mathrm{GABA}_{\mathrm{B} 1 \mathrm{a}}$ and $\mathrm{GABA}_{\mathrm{B} 1 \mathrm{~b}}$ cannot compensate for each other in response to synaptically released GABA is important from a pharmaceutical perspective. The existence of two functionally distinct $\mathrm{GABA}_{\mathrm{B}}$ receptor subtypes enables a more selective interference with the $\mathrm{GABA}_{\mathrm{B}}$ receptor system, which may be of therapeutic benefit for the treatment of neurological and psychiatric disorders (Tiao et al., 2008).

\section{References}

Alle H, Geiger JR (2006) Combined analog and action potential coding in hippocampal mossy fibers. Science 311:1290-1293.

Bettler B, Kaupmann K, Mosbacher J, Gassmann M (2004) Molecular structure and physiological functions of $\mathrm{GABA}_{\mathrm{B}}$ receptors. Physiol Rev 84:835-867.

Calver AR, Davies CH, Pangalos M (2002) $\mathrm{GABA}_{\mathrm{B}}$ receptors: from monogamy to promiscuity. Neurosignals 11:299-314.

Chandler KE, Princivalle AP, Fabian-Fine R, Bowery NG, Kullmann DM, Walker MC (2003) Plasticity of $\mathrm{GABA}_{\mathrm{B}}$ receptor-mediated heterosynaptic interactions at mossy fibers after status epilepticus. J Neurosci 23:11382-11391.

Cunha RA (2008) Different cellular sources and different roles of adenosine: A1 receptor-mediated inhibition through astrocytic-driven volume transmission and synapse-restricted A2A receptor-mediated facilitation of plasticity. Neurochem Int 52:65-72.

Dittert I, Benedikt J, Vyklický L, Zimmermann K, Reeh PW, Vlachová V (2006) Improved superfusion technique for rapid cooling or heating of cultured cells under patch-clamp conditions. J Neurosci Methods 151:178-185.

Fritschy JM, Meskenaite V, Weinmann O, Honer M, Benke D, Mohler H (1999) $\mathrm{GABA}_{\mathrm{B}}$-receptor splice variants GB1a and GB1b in rat brain: developmental regulation, cellular distribution and extrasynaptic localization. Eur J Neurosci 11:761-768.

Hawrot E, Xiao Y, Shi QL, Norman D, Kirkitadze M, Barlow PN (1998) Demonstration of a tandem pair of complement protein modules in $\mathrm{GABA}_{\mathrm{B}}$ receptor 1a. FEBS Lett 432:103-108.

Huang ZJ (2006) GABAB receptor isoforms caught in action at the scene. Neuron 50:521-524.

Isaacson JS, Solís JM, Nicoll RA (1993) Local and diffuse synaptic actions of GABA in the hippocampus. Neuron 10:165-175.

Jacobson LH, Kelly PH, Bettler B, Kaupmann K, Cryan JF (2007) Specific roles of $\mathrm{GABA}_{\mathrm{B}(1)}$ receptor isoforms in cognition. Behav Brain Res 181:158-162.

Jarolimek W, Misgeld U (1997) GABA $_{B}$ receptor-mediated inhibition of tetrodotoxin-resistant GABA release in rodent hippocampal CA1 pyramidal cells. J Neurosci 17:1025-1032.

Jensen K, Chiu CS, Sokolova I, Lester HA, Mody I (2003) GABA transporter-1 (GAT1)-deficient mice: differential tonic activation of $\mathrm{GABA}_{\mathrm{A}}$ versus $\mathrm{GABA}_{\mathrm{B}}$ receptors in the hippocampus. J Neurophysiol 90:2690-2701.

Jin W, Chavkin C (1999) Mu opioids enhance mossy fiber synaptic transmission indirectly by reducing $\mathrm{GABA}_{\mathrm{B}}$ receptor activation. Brain Res 821:286-293

Kamiya H, Shinozaki H, Yamamoto C (1996) Activation of metabotropic glutamate receptor type $2 / 3$ suppresses transmission at rat hippocampal mossy fibre synapses. J Physiol 493:447-455.

Karschin A (1999) G protein regulation of inwardly rectifying $\mathrm{K}^{+}$channels. News Physiol Sci 14:215-220.

Kirschstein T, von der Brelie C, Steinhäuser M, Vinçon A, Beck H, Dietrich D (2004) L-CCG-I activates group III metabotropic glutamate receptors in the hippocampal CA3 region. Neuropharmacology 47:157-162.

Kulik A, Nakadate K, Nyíri G, Notomi T, Malitschek B, Bettler B, Shigemoto R (2002) Distinct localization of $\mathrm{GABA}_{\mathrm{B}}$ receptors relative to synaptic 
sites in the rat cerebellum and ventrobasal thalamus. Eur J Neurosci 15:291-307.

Kulik A, Vida I, Luján R, Haas CA, López-Bendito G, Shigemoto R, Frotscher M (2003) Subcellular localization of metabotropic $G_{A B A}$ receptor subunits $\mathrm{GABA}_{\mathrm{B}(1 \mathrm{a} / \mathrm{b})}$ and $\mathrm{GABA}_{\mathrm{B}(2)}$ in the rat hippocampus. J Neurosci 23:11026-11035.

Kulik A, Vida I, Fukazawa Y, Guetg N, Kasugai Y, Marker CL, Rigato F, Bettler B, Wickman K, Frotscher M, Shigemoto R (2006) Compartmentdependent colocalization of Kir3.2-containing $\mathrm{K}^{+}$channels and $\mathrm{GABA}_{\mathrm{B}}$ receptors in hippocampal pyramidal cells. J Neurosci 26:4289-4297.

Lacey CJ, Boyes J, Gerlach O, Chen L, Magill PJ, Bolam JP (2005) GABA receptors at glutamatergic synapses in the rat striatum. Neuroscience 136:1083-1095.

Lei S, McBain CJ (2003) GABA $_{B}$ receptor modulation of excitatory and inhibitory synaptic transmission onto rat CA3 hippocampal interneurons. J Physiol 546:439-453.

Liu X, Tribollet E, Raggenbass M (2006) $\mathrm{GABA}_{\mathrm{B}}$ receptor-activation inhibits GABAergic synaptic transmission in parvocellular neurones of rat hypothalamic paraventricular nucleus. J Neuroendocrinol 18:177-186.

López-Bendito G, Shigemoto R, Kulik A, Vida I, Fairén A, Luján R (2004) Distribution of metabotropic GABA receptor subunits $\mathrm{GABA}_{\mathrm{Bla} / \mathrm{b}}$ and $\mathrm{GABA}_{\mathrm{B} 2}$ in the rat hippocampus during prenatal and postnatal development. Hippocampus 14:836-848.

Lüscher C, Jan LY, Stoffel M, Malenka RC, Nicoll RA (1997) G proteincoupled inwardly rectifying $\mathrm{K}^{+}$channels (GIRKs) mediate postsynaptic but not presynaptic transmitter actions in hippocampal neurons. Neuron 19:687-695.

Malitschek B, Rüegg D, Heid J, Kaupmann K, Bittiger H, Fröstl W, Bettler B, Kuhn R (1998) Developmental changes in agonist affinity at $\mathrm{GABA}_{\mathrm{B}(1)}$ receptor variants in rat brain. Mol Cell Neurosci 12:56-64.

Manzoni OJ, Manabe T, Nicoll RA (1994) Release of adenosine by activation of NMDA receptors in the hippocampus. Science 265:2098-2101.

Misgeld U, Bijak M, Jarolimek W (1995) A physiological role for $\mathrm{GABA}_{\mathrm{B}}$ receptors and the effects of baclofen in the mammalian central nervous system. Prog Neurobiol 46:423-462.

Nicoll RA, Schmitz D (2005) Synaptic plasticity at hippocampal mossy fibre synapses. Nat Rev Neurosci 6:863-876.

Pérez-Garci E, Gassmann M, Bettler B, Larkum ME (2006) The GABA ${ }_{\mathrm{B} 1 \mathrm{~b}}$ isoform mediates long-lasting inhibition of dendritic $\mathrm{Ca}^{2+}$ spikes in layer 5 somatosensory pyramidal neurons. Neuron 50:603-616.

Price CJ, Cauli B, Kovacs ER, Kulik A, Lambolez B, Shigemoto R, Capogna M (2005) Neurogliaform neurons form a novel inhibitory network in the hippocampal CA1 area. J Neurosci 25:6775-6786.

Sakaba T, Neher E (2003) Direct modulation of synaptic vesicle priming by $\mathrm{GABA}_{\mathrm{B}}$ receptor activation at a glutamatergic synapse. Nature 424:775-778.

Scanziani M (2000) GABA spillover activates postsynaptic $\mathrm{GABA}_{\mathrm{B}}$ receptors to control rhythmic hippocampal activity. Neuron 25:673-681.

Scanziani M, Capogna M, Gähwiler BH, Thompson SM (1992) Presynaptic inhibition of miniature excitatory synaptic currents by baclofen and adenosine in the hippocampus. Neuron 9:919-927.

Schuler V, Lüscher C, Blanchet C, Klix N, Sansig G, Klebs K, Schmutz M, Heid J, Gentry C, Urban L, Fox A, Spooren W, Jaton AL, Vigouret J, Pozza M, Kelly PH, Mosbacher J, Froestl W, Käslin E, Korn R, et al. (2001) Epilepsy, hyperalgesia, impaired memory, and loss of pre- and postsynaptic $\mathrm{GABA}_{\mathrm{B}}$ responses in mice lacking $\mathrm{GABA}_{\mathrm{B}(1)}$. Neuron 31:47-58.

Shaban H, Humeau Y, Herry C, Cassasus G, Shigemoto R, Ciocchi S, Barbieri S, van der Putten H, Kaupmann K, Bettler B, Lüthi A (2006) Generalization of amygdala LTP and conditioned fear in the absence of presynaptic inhibition. Nat Neurosci 9:1028-1035.

Steiger JL, Bandyopadhyay S, Farb DH, Russek SJ (2004) cAMP response element-binding protein, activating transcription factor- 4 , and upstream stimulatory factor differentially control hippocampal $\mathrm{GABA}_{\mathrm{B}} \mathrm{R} 1 \mathrm{a}$ and $\mathrm{GABA}_{\mathrm{B}} \mathrm{R} 1 \mathrm{~b}$ subunit gene expression through alternative promoters. J Neurosci 24:6115-6126.

Tiao JY, Bradaia A, Biermann B, Kaupmann K, Metz M, Haller C, Rolink AG, Pless E, Barlow PN, Gassmann M, Bettler B (2008) The sushi domains of secreted $G_{A B A}$ isoforms selectively impair $G_{B B A}$ heteroreceptor function. J Biol Chem 283:31005-31011.

Tosetti P, Bakels R, Colin-Le Brun I, Ferrand N, Gaiarsa JL, Caillard O (2004) Acute desensitization of presynaptic $\mathrm{GABA}_{\mathrm{B}}$-mediated inhibition and induction of epileptiform discharges in the neonatal rat hippocampus. Eur J Neurosci 19:3227-3234.

Ulrich D, Bettler B (2007) $\mathrm{GABA}_{\mathrm{B}}$ receptors: synaptic functions and mechanisms of diversity. Curr Opin Neurobiol 17:298-303.

Ulrich D, Besseyrias V, Bettler B (2007) Functional mapping of $\mathrm{GABA}_{\mathrm{B}}$ receptor subtypes in the thalamus. J Neurophysiol 98:3791-3795.

Vida I, Frotscher M (2000) A hippocampal interneuron associated with the mossy fiber system. Proc Natl Acad Sci U S A 97:1275-1280.

Vigot R, Barbieri S, Bräuner-Osborne H, Turecek R, Shigemoto R, Zhang YP, Luján R, Jacobson LH, Biermann B, Fritschy JM, Vacher CM, Müller M, Sansig G, Guetg N, Cryan JF, Kaupmann K, Gassmann M, Oertner TG, Bettler B (2006) Differential compartmentalization and distinct functions of $\mathrm{GABA}_{\mathrm{B}}$ receptor variants. Neuron 50:589-601.

Vogt KE, Nicoll RA (1999) Glutamate and gamma-aminobutyric acid mediate a heterosynaptic depression at mossy fiber synapses in the hippocampus. Proc Natl Acad Sci U S A 96:1118-1122.

Weisskopf MG, Zalutsky RA, Nicoll RA (1993) The opioid peptide dynorphin mediates heterosynaptic depression of hippocampal mossy fibre synapses and modulates long-term potentiation. Nature 365:188.

Yamada J, Saitow F, Satake S, Kiyohara T, Konishi S (1999) GABA $_{(B)}$ receptor-mediated presynaptic inhibition of glutamatergic and GABAergic transmission in the basolateral amygdala. Neuropharmacology 38:1743-1753.

Yeckel MF, Kapur A, Johnston D (1999) Multiple forms of LTP in hippocampal CA3 neurons use a common postsynaptic mechanism. Nat Neurosci 2:625-633. 